\title{
HUBUNGAN PERILAKU PERDAGANGAN INVESTOR DENGAN VOLUME PERDAGANGAN DI BURSA EFEK INDONESIA
}

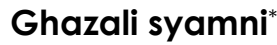

\author{
Dosen Fakultas Ekonomi Universitas Malikussaleh Lhokseumawe
}

\begin{abstract}
This paper examines the relationship of behavior trading investor using data detailed transaction history-corporate edition demand and order history in Indonesia Stock Exchange during period of March, April and May 2005. Peculiarly, behavior placing of investor order at trading volume. The result of this paper indicates that trading volume order pattern to have pattern $U$ shape. The pattern happened that investors have strong desires to places order at the opening and close of compared to in trading periods. While the largest orders are of market at the opening indicates that investor is more conservatively when opening, where many orders when opening has not happened transaction to match. In placing order both of investor does similar strategy. By definition, informed investors orders more large than uninformed investors. If comparison of order examined hence both investors behavior relatively changes over time. But, statistically shows there is not ratio significant. This imply behavior trading of informed investors and uninformed investors stable relative over time. The result from regression analysis indicates that informed investors to correlate at trading volume in all time intervals, but not all uninformed investors correlates in every time interval. This imply investor order inform is more can explain trading volume pattern compared to uninformed investor order in Indonesia Stock Exchange. Finally, result of regression also finds that order status match has greater role determines trading volume pattern intraday especially informed buy match and informed sale match. While amend, open and withdraw unable to have role to determine intraday trading volume pattern.
\end{abstract}

Keywords: Behavior of investors, Trading volume, Conservative investors and Order status. 


\section{PENDAHULUAN}

\section{Latar Belakang}

Perubahan peraturan atau sistem perdagangan tradisional ke elektronik akan meningkatkan volume perdagangan di suatu pasar bursa saham. Peningkatan volume perdagangan dikarenakan pasar menyediakan informasi lebih lengkap, seperti informasi transaksi sebelumnya, informasi permintaan dan penawaran saham. Dengan tersedianya informasi membuat pasar lebih efisiensi dan transparan karena investor memiliki kemampuan untuk mengamati informasi yang relevan (Brockman dan Chung 2000). Berbagai penelitian empiris menemukan bahwa situasi pasar keuangan paling aktif pada awal (pembukaan) dan akhir sesi (penutupan) pasar perdagangan (Brock dan Kleidon 1991; Gerety dan Mulherin 1992; Lee, Fok dan Liu 2001; Admati dan Pfeiderer 1988; Ho dan Cheung 1991; Mclnish dan Wood 1991; Abhyankar, Levin dan Limmack 1997).

Di sisi lain, meskipun pasar telah menyediakan informasi, namun informasi tersebut dicerna beragam oleh investor. Easley, Keifer, O'Hara dan Paperman (1996) dalam Brockman dan Chung (2000) mengatakan ada dua tipe investor dalam mencerna suatu informasi, yaitu; informed dan uninformed investors. Easley et al. (1996) dalam Brockman dan Chung (2000) mendefinisikan informed investors adalah investor yang dapat menangkap semua hal yang berkaitan dengan proses perdagangan dan mengetahui kapan melakukan order beli dan order jual di semua peristiwa, seperti: informasi privat dan berita baik atau buruk. Sedangkan uninformed investors didefinisikan sebagai investor kurang atau tidak mempunyai kesadaran adanya peristiwa informasi (privat), berita baik dan buruk.

Lee, Fok dan Liu (2001) mengatakan informed investors menempatkan order lebih besar dibandingkan dengan uninformed investors pembukaan dan penutupan pasar daripada periode dalam perdagangan. Hal tersebut terjadi karena investor paling konservatif pada pembukaan pasar dan melakukan strategi dalam menempatkan order. Lee, Fok dan Liu (2001) mengatakan investor konservatif yaitu investor menempatkan order lebih besar pada pembukaan pasar, dan besarnya order pada pembukaan pasar belum tentu mengarah kepada terjadinya perdagangan. Sedangkan investor melakukan strategi, mereka mendefinisikan dengan order informed investors lebih besar dari uninformed investors

Penelitian Slezak (1994) mengatakan perilaku konservatif investor tersebut karena investor menghindari risiko. Alasannya, antara lain: pertama, adanya perbedaan rata-rata return yang simultan, dimana investor tidak dapat memastikan informasi dengan presisi tinggi dan tidak ada pedagang yang superior dalam informasi dan selalu ada adverse selection walaupun tiap investor menerima distribusi sinyal semua informasi sama. Kedua, 
berhubungan pada pembuatan kesimpulan yang tidak sempurna dalam dinamik harga. Ketiga, ketidakpastian batas pembayaran akhir posisi agen. Motivasi penelitian ini adalah karena kebanyakan penelitian sebelumnya menggunakan data harian dan pengamatanpengamatan mingguan mungkin gagal menangkap informasi spontan yang terdapat dalam pergerakan pasar intraday. Dengan demikian, pengujian perilaku volume perdagangan investor pada pasar modal Indonesia berdasar data intraday perlu dilakukan. Penelitian ini menguji perilaku perdagangan investor saat pembukaan dan penutupan pasar serta hubungan perilaku perdagangan investor dengan volume perdagangan melalui pendekatan mikrostruktur pasar di Bursa Efek Indonesia.

Penelitian ini dilakukan untuk menanggapi dua isu tersebut di atas. Isu pertama adalah apakah perubahan mekanisme perdagangan elektronik mempengaruhi perilaku investor. Sedangkan isu berikutnya adalah apakah perubahan peraturan akan mempengaruhi perilaku perdagangan investor di Bursa efek Indonesi.

\section{Rumusan Masalah}

Berdasarkan latar belakang penelitian yang telah dikemukakan di atas, maka rumusan masalah dalam penelitian ini adalah:

1. Apakah investor cenderung menempatkan order pada pembukaan dan penutupan pasar?

2. Apakah investor lebih konservatif dalam menempatkan order pada pembukaan pasar dibandingkan dengan penutupan pasar?

3. Apakah investor melakukan strategi dalam menempatkan order pada pembukaan pasar?

4. Apakah penempatan order informed dan uninformed investors berhubungan dengan volume perdagangan?

\section{Tujuan Penelitian}

Adapun tujuan dari penelitian ini adalah:

1. Untuk menguji perilaku investor dalam menempatkan order saat pembukaan dan penutupan pasar.

2. Untuk menguji perilaku konservatif investor dalam menempatkan order pada pembukaan pasar dan penutupan pasar.

3. Untuk menguji strategi investor dalam menempatkan order pada pembukaan pasar.

4. Untuk menguji hubungan penempatan order informed dan uninformed investors dengan volume perdagangan. 


\section{KERANGKA TEOTITIS dan PENGEMBANGAN HIPOTESIS}

\section{Perilaku Perdagangan Investor dalam Menempatkan order.}

Penelitian Mclnish dan Wood (1991) yang menguji perilaku perdagangan intraday dan return overnight. Hasil penelitian mengindikasikan adanya pengaruh day-of-the week khususnya saham-saham yang teraktif. Ho dan Cheung (1991) yang menguji perilaku intra-daily return di pasar bursa Hongkong menemukan bahwa volume perdagangan pada the end of day lebih besar dibandingkan dengan pada hari istirahat. Abhyankar, Levin dan Limmack (1997) yang menguji variasi intraday bid-ask, volume perdagangan dan volatilitas saham di London Stock Exchange menemukan intraday spreads lebih tinggi pada saat pembukaan dan selanjutnya konstan dan sedikit turun pada saat penutupan.

Sedangkan Admati dan Pfeiderer (1988) dan Lee, Fok dan Liu (2001) menguji hubungan perilaku investor berinformasi dengan volume perdagangan. Penelitian tersebut menemukan investor cenderung menempatkan order lebih besar saat pembukaan pasar dan penutupan pasar. Segara dan Segara (2007) yang melakukan pengujian pola perdagangan intraday volume perdagangan pada ekuitas waran dan ekuitas option di pasar keuangan Australia. Hasil temuannya adalah perdagangan sangat tinggi pada pembukaan pasar dan akan menurun pada penutupan pasar.

\section{H1: Investor cenderung menempatkan order terbesar pada pembukaan dan penutupan pasar dari periode dalam perdagangan.}

Perilaku Konservatif Investor dan Strategi Investor dalam Menempatkan order.

Kebanyakan penelitian empiris sebelumnya menjelaskan bahwa investor menempatkan order terbesar pada pembukaan pasar. Tetapi, Besanya total order pada pembukaan pasar belum tentu dapat dikatakan sebagai ukuran keinginan investor melakukan transaksi perdagangan, karena masih banyak order pada pembukaan pasar yang belum dieksekusi. Penelitian Admati dan Pfleiderer (1988 dan 1989) menjelaskan bahwa likuiditas investor berinformasi dan tidak berinformasi cenderung mengelompok pada pembukaan dan penutupan pasar. menurut (Lee, Fok dan Liu 2001) menjelaskan terjadinya pengumpulan order terbesar pada pembukaan menunjukkan bahwa investor menempatkan order lebih konservatif pada pembukaan pasar. 
Foster dan Viswanathan (1990) mengatakan investor berinformasi lebih bijaksana memasuki pasar untuk menghindari adanya pikiran informasi privat. Wang (1994) mengungkapkan bahwa para pedagang yang memiliki informasi kemungkinan lebih tinggi melakukan perdagangan dari pedagang kurang memiliki informasi yang cenderung kurang berpartisipasi dalam pasar. Foster dan Viswanathan (1994) mengatakan investor melakukan strategi dalam perdagangan. Obizhaeva dan Wang (2006) mengatakan penawaran dan permintaan sekuritas di dalam pasar adalah intertemporal, bukan statis. Sedangkan Lee, Fok dan Liu (2001) mengatakan bahwa kedua investor melakukan strategi yakni keduanya menempatkan order lebih konservatif pada pembukaan pasar dengan definisi order informed lebih besar dari order uninformed.

\section{H3: Investor melakukan strategi pada pembukaan pasar}

\section{Hubungan Perilaku Perdagangan Investor dengan Volume Perdagangan.}

Adanya perbedaan dalam mencerna informasi, maka lahirlah pengelompokkan investor kedalam informed investors dan uninformed investors (Easley, Keifer, O'Hara dan Paperman 1996 dalam Brockman dan Chung 2000). Penelitian Lee, Fok dan Liu (2001) menemukan bahwa penempatan order informed investors dan uninformed investors berhubungan signifikan dengan volume perdagangan. Penelitian Lee, Fok dan Liu (2001) tersebut mengatakan bahwa perdagangan berinformasi dan perdagangan kurang berinformasi keduanya dapat menjelaskan pola perilaku volume perdagangan. Dan pengaruh perdagangan kurang berinformasi relatif lebih besar terhadap volume perdagangan.

H4: Penempatan order investor berhubungan dengan volume perdagangan pada setiap waktu.

\section{METODE PENELITIAN}

\section{Data dan Sampel}

PT. Bursa Efek Indonesia (BEI) menggunakan Jakarta Automated Trading System (JATS) dalam mekanisne perdagangan sejak 22 Mei 1995 dan menganut sistem order driven market. Kegiatan perdagangan di BEl diadakan pada hari exchange days, yaitu hari Senin sampai Kamis mulai jam 09:30-12:00 WIB (sesi pagi) dan jam 13:30-16:00 WIB (sesi siang) serta hari Jumat jam 09:30-1 1:30 (sesi pagi) dan jam 14:00-16:00 WIB (sesi siang). Informasi tentang perdagangan sekuritas langsung dapat dilihat di Jakarta Stock exchange Real Time 
Information (JSX-RTI). Sebelum kegiatan perdagangan dibuka BEI memberlakukan preopening yang dimulai jam 09:10-09:30 WIB pada beberapa saham.

Penelitian ini menggunakan data detailed transaction history-corporate edition demand \& order history intraday bulan Maret, April dan Mei tahun 2005, saham yang termasuk dalam pre-opening dan LQ-45 di Bursa Efek Indonesia. Penggunaan data saham LQ 45 karena saham tersebut paling aktif dan representatif dalam periode sampel perdagangan. Selanjutnya dalam mengidentifikasi perbedaan tipe perilaku perdagangan informed investors melakukan order lebih dari 20 lot, dan uninformed investors yang melakukan order kurang dari atau sama dengan 20 lot (Lee, Fok dan Liu 2001).

\section{Pola Volume Perdagangan Intraday}

Pola intraday volume perdagangan dalam penelitian ini menggunakan interval waktu 15 menit dengan mencari pola volume perdagangan di BEl, yaitu:

- Point pertama adalah jam 09:10-09:30 WIB sebagai representasi yang merepresentasikan pembukaan perdagangan (pre opening).

- Point interior adalah 09:45-1 1:45 WIB merepresentasikan periode interior sesi pagi (inn).

- Poin terakhir sesi pagi yaitu 12:00 WIB (close) pagi.

- Poin pertama yaitu jam 13.45 WIB pembukaan perdagangan sesi siang.

- Poin interior 13:45-15:45 WIB (inn) siang.

- Poin penutupan jam 16:00 WIB (close) siang.

- Mengumpulkan jumlah order saham dalam hari perdagangan

\section{Pengukuran Variabel}

\section{Investor Desires (keinginan investor)}

Dalam menentukan keinginan investor ada 2 hal menjadi trade-off bagi investor, yaitu prioritas harga dengan biaya tunggu (waiting cost) dalam penempatan order dan terjadinya order tersebut. Dari trade-off ini dapat dilihat kemungkinan terjadinya order. Jika para investor (pedagang) berkeinginan menempatkan harga order rendah (tinggi) untuk membeli (menjual) saham, ini berarti investor ini menunggu peluang terbaik untuk mendapat harga lebih baik. Jika ada order yang tidak terjadi dieksekusi hal tersebut mencerminkan bahwa keinginan investor/ pedagang lebih pada prioritas harga atau kurang berminat melakukan perdagangan. 
Namun, jika investor menempatkan harga order yang tinggi (rendah) untuk membeli (menjual) saham, artinya mereka berkeinginan besar agar order dieksekusi. Maka hal tersebut menunjukkan bahwa investor lebih berkeinginan melakukan perdagangan terjadi dan tidak berprioritas harga. Jika keinginan investor lebih kuat untuk menempatkan order pada pembukaan dan penutupan pasar maka pola bentuk $U$ akan ditemukan pada order pembelian dan penjualan riil. Berdasarkan dari dua trade- off tersebut maka klasifikasi total order, yaitu:

- Total order pembelian (Bi,t) pada interval i pada hari t, dan Total order penjualan (S i,t) pada interval i pada hari t. Total order dalam transaksi tersebut memiliki status order yang memilki nomor urut antara lain Amend order (A), Match order (M), Withdraw order (W) dan Open order (O).

- Bentuk order diukur dalam bentuk perdagangan lot, 1 lot sama dengan 500 lembar saham.

- Amend order (A): adalah order-order yang dirubah sebelum menjadi transaksi atau match.

- Match order (M): adalah status order yang telah terjadi proses alokasi atau penyimpanan order jual dengan order beli atas saham yang sama berdasarkan harga terbaik/ dilihat dari sisi jual dan beli.

- Open order (O): adalah order-order yang belum teralokasi atau baru sebagian teralokasi.

- Withdraw order (W): adalah status order-order yang ditarik kembali sebelum terjadi transaksi/ belum teralokasi match.

- Session: adalah dalam satu hari transaksi ada dua sesi yaitu pagi dan siang.

- Ukuran interval i adalah 15 menit.

\section{Informed Investors dan Uninformed Investors}

Dalam menentukan ukuran informed dan uninformed investors, penelitian ini mengacu pada Lee, Fok dan Liu (2001) yang mengklasifikasikan informed dan uninformed investors berdasarkan ukuran order dalam bentuk lot. Informed investors adalah investor yang melakukan order lebih dari 20 lot, sedangkan uninformed investors melakukan order kurang dari 20 lot.

\section{Proses Analisis Data}

Dalam menganalisis data dilakukan pemilihan saham yang termasuk dalam LQ-45 dan pre-opening maka terpilih 33 saham saja. Setelah mendapatkan data saham-saham tersebut, maka dilakukan proses analisis data dan langkah-langkah sebagai berikut: 
1. Membagi total order dalam order penjualan dan order pembelian berdasarkan lot waktu pembukaan (pre-opening yaitu, jam 9:10-09:30 WIB) sampai penutupan pasar dalam interval waktu 15 menit.

2. Total order dalam order penjualan dan order pembelian dikelompok kembali berdasarkan status ordernya yaitu Amend order (A), Match order (M), Open (O) order dan Withdraw order (W) dalam interval waktu 15 menit mulai sesi pertama (pagi) dan sesi kedua (siang) dari pembukaan sampai penutupan.

3. Selanjutnya membagi order-order yang telah memiliki status order Amend, Match, Open dan Withdraw ke dalam kelompok informed dan uninformed.

4. Melakukan Analisis of Variance-Anova untuk hipotesis 1, hipotesis 2 dan hipotesis 3 dari total order (pembelian + penjualan) saat pembukaan dan penutupan dibandingkan dengan periode interior dan melihat nilai statistik F-open, Inn; F-close, inn dibandingkan dengan periode interior atau F-Inn.

5. Melakukan regresi untuk menguji hipotesis 4, yaitu hubungan kedua investor baik informed investors dan uninformed investors dalam menempatkan order dengan volume perdagangan. Hasil regresi tersebut akan menjelaskan peran informed dan uninformed investors dengan volume perdagangan.

\section{TEKNIK PENGUJIAN HIPOTESIS dan METODE ANALISIS DATA}

\section{Pengujian Tahap Pertama: Analisis of Variance}

Pengujian hipotesis 1, hipotesis 2 dan hipotesis 3 dilakukan dengan ANOVA. Esensi pengujian ini adalah ingin menguji perbedaan yang signifikan antara kelompok data. Asumsi yang digunakan dalam pengujian ANOVA, yaitu: populasi-populasi yang diuji berdistribusi normal, varian dari populasi-populasi adalah sama (Santoso, 2007). Hipotesis pertama yaitu investor cenderung menempatkan order pada pembukaan dan penutupan pasar dilakukan sebagai berikut:

a. Mendistribusikan data order pembelian dan penjualan kedalam interval waktu 15 menit dimana sesi pertama terdapat 11 interval dan sesi kedua 10 interval.

b. Pembukaan perdagangan (pre opening) jam 09:10-09:30 WIB, perdagangan 15 menit selanjutnya merupakan interval waktu perdagangan mulai jam 09:45-1 1:45 WIB sebagai periode interior (periode inn) dan jam 12:00 akhir perdagangan sesi pagi.

c. Sedangkan untuk sesi siang tidak ada opening, mulai perdagangan dari jam 13:30 WIB sampai jam 15:45 WIB waktu perdagangan dan jam 16:00 WIB adalah akhir perdagangan.

d. Melakukan uji $\mathrm{F}$ (Analisis of Variance-Anova) untuk mengindikasikan total order (pembelian + penjualan) saat pembukaan dan penutupan dibandingkan dengan periode interior dan mencari nilai statistik F-open, Inn, F-close, inn dibandingkan dengan F-inn.

e. Jika hasil uji $\mathrm{F}$ pada saat pembukaan dan penutupan lebih besar dengan periode interior, maka hipotesis pertama didukung. 
f. Sedangkan untuk menguji sifat konservatif investor pada waktu pembukaan dan penutupan perdagangan (Hipotesis 2). Langkah-langkah yang dilakukan adalah;

- Membagi status order match dengan 3 status order amend, open dan withdraw pada pembukaan dan penutupan pasar perdagangan.

- Jika hasil uji F pada pembukaan dan penutupan pasar untuk order match lebih rendah dari status order lainnya, maka hipotesis pertama didukung.

g. Selanjutnya untuk menguji strategi investor dalam menempatkan order pada pembukaan dan penutupan pasar dalam sesi interval perdagangan (Hipotesis 3). Maka dapat dilakukan, dengan;

- Mengklasifikasikan order dalam order inform dan order uninformed berdasarkan status order yaitu: status Amend order (A), Match order (M), Open (O) order dan Withdraw order (W), dimana status order tersebut diklasifikasi berdasarkan order pembelian dan penjualan.

- Dalam menganalisis strategi yang dilakukan oleh investor dalam menempatkan order di lakukukan dengan mencari rasio informed dengan uninformed investors.

\section{Pengujian Tahap Kedua: Analisis Regresi}

Analisis regresi ini dilakukan untuk menginvestigasi hubungan informed dan uninformed investors dalam menempatkan order dengan volume perdagangan. Hasil regresi tersebut menjelaskan peran informed dan uninformed investors pada volume perdagangan, maka model persamaan regresi yang digunakan adalah:

$V_{O}=L_{t}=a_{0}+a_{1} I N F B t+a 2 I N F S t+a 3$ UNFBt+ a 4 UNFSt $+\varepsilon t$,

Dimana, $\mathrm{VOL}_{t}=$ volume perdagangan pada waktu interval $\mathrm{t}, \quad \mathrm{INFB}_{\mathbf{t}}=$ pembelian order informed investors interval $t, \mathrm{INFS}_{t}=$ penjualan order informed investors interval $t, \mathrm{UNFB}_{\boldsymbol{t}}=$ pembelian order uninformed investors interval $t, \mathrm{UNFS}_{\boldsymbol{t}}=$ penjualan order uninformed investors interval $t$.

Selanjutnya melakukan regresi untuk menguji dampak status order dengan volume perdagangan. Maka model persamaan regresi yang digunakan adalah:

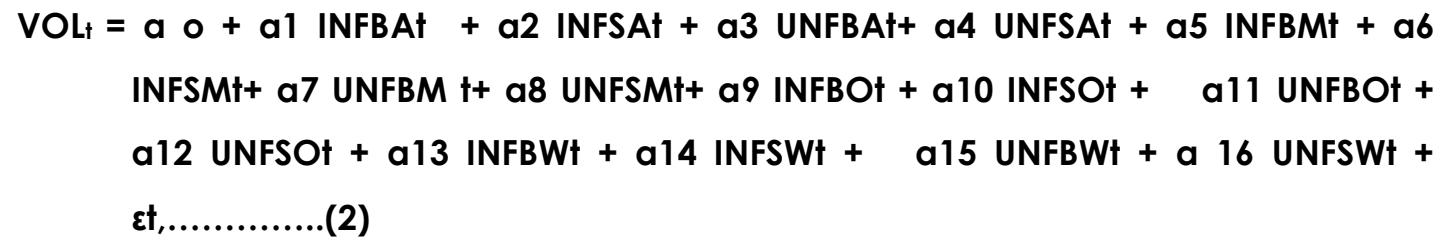

Dimana, variabel independen dari persamaan tersebut yaitu INF dan UNF yang merupakan informed dan uninformed investors. Huruf $S$ dan B identitas dari order beli (B) dan jual (S). 
Sedangkan huruf terakhir merupakan status-status order Amend order (A), Match order (M), Open order (O) dan Withdraw order (W).

\section{Analisis Data}

Dalam bagian analisis data penelitian ini berdasarkan metode yang telah diuraikan sebelumnya. Dimulai dengan melihat pola perilaku intraday volume perdagangan menggunakan 33 sampel perusahaan yang termasuk dalam saham pra-pembukaan dan LQ-45 di Bursa Efek Indonesia (BEI). Selanjutnya membahas pengujian Analysis of Variance (ANOVA) untuk hipotesis pertama, kedua dan ketiga. Sedangkan hipotesis terakhir menggunakan analisis regresi untuk menguji hubungan perilaku investor pada volume perdagangan dalam penempatan ordernya.

\section{Pola Perilaku perdagangan Investor dalam menempatkan order.}

Berdasarkan distribusi order beli dan jual diukur dalam lot dengan interval 15 menit terdapat 21 interval intraday perdagangan, semua order pembelian dan order penjualan. Sesi pertama (open) merupakan indikasi akumulasi order dari jam 09:10-09:30, selainnya interval 15 menit selanjutnya. Gambar 1, waktu yang ditunjukkan pada gambar tersebut merupakan akhir 15 menit suatu interval. Misalnya, interval kedua 09:45 adalah posisi periode waktu dari jam 09:30-09:45 diluar waktu pra-pembukaan. Interval terakhir dalam sesi pagi jam 16:00 merupakan posisi waktu dari jam 15:45-16:00. Sedangkan interval dari jam 09:45-15:45 sebagai definisi periode inn. Gambar 1 memperlihatkan bahwa pola perilaku investor pola $U$, hal ini menunjukkan total order terbesar terjadi pada pembukaan pasar dan turun secara dramatis mulai interval selanjutnya dan sedikit naik pada penutupan pasar.

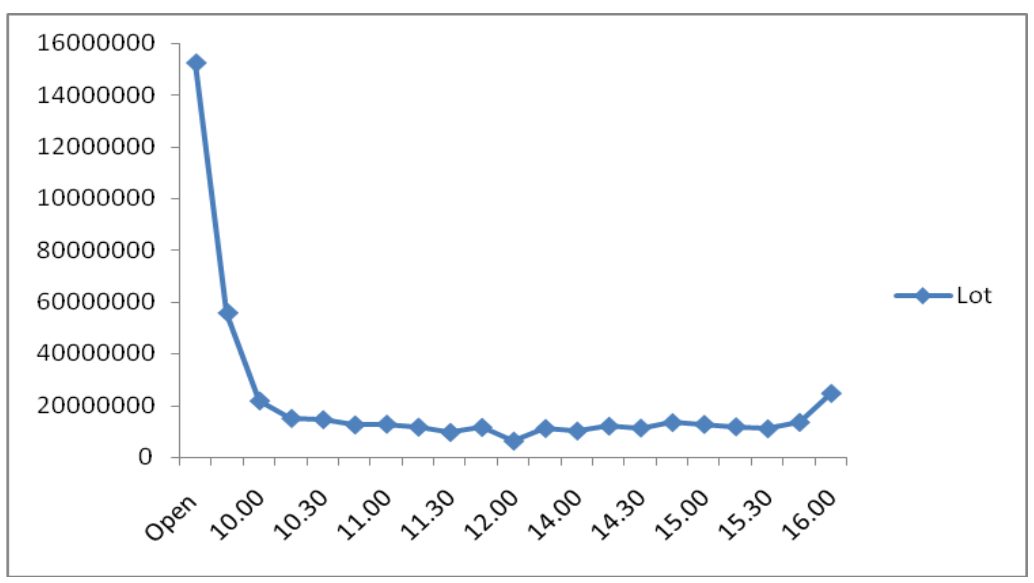

Sumber: Data diolah ( 2008)

\section{Gambar 1}




\section{PEMBAHASAN dan KESIMPULAN}

\section{Pembahasan}

\section{a. Perilaku Investor Menempatkan Order Terbesar pada Pembukaan dan Penutupan Pasar dari Periode dalam Perdagangan.}

Pada pembukaan pasar di Tabel 1, lot order jual sebesar 97.256.367,75 dibandingkan dengan order lot beli yaitu 54.997.984,00. Sedangkan pada penutupan pasar order lot jual dan order lot beli relatif berimbang dengan order lot jual 12.514.839,60 dan order lot beli 12.040.657,00. Hal ini berarti, besarnya order penjualan pada pembukaan pasar merupakan refleksi tingginya ketidakpastian pada waktu tersebut. Hasil temuan ini sesuai dengan Admati dan Pfeiderer (1988), Lee, Fok dan Liu (2001), Wood, Mclnish dan Ord (1985), Brock dan Kleidon (1991), Abhyankar, Levin dan Limmack (1997) serta Lee, Fok dan Liu (2001).

Hasil uji $F$ tersebut juga menunjukkan nilai perbedaan yang signifikan tinggi pada pembukaan dan penutupan pasar, yaitu; F-open, Inn intraday $=6,981$ dan F-close, Inn intraday= 4,130 serta F-inn intraday $=3,408$ (Lihat Tabel 1). Temuan tersebut mendukung hipotesis pertama yang mengatakan bahwa investor menempatkan order terbesar pada pembukaan dan penutupan pasar dibandingkan dari periode dalam perdagangan.

\section{b. Sifat Konservatif Investor pada Pembukaan Pasar}

Dalam Tabel 1 di atas terlihat bahwa total order volume perdagangan terbesar muncul pada pembukaan dan menjelang penutupan pasar. Besarnya total order tersebut belum tentu dapat dikatakan sebagai keinginan investor dalam melakukan perdagangan match atau investor hanya "menguji" pasar dengan menempatkan order dan tidak untuk dieksekusi. Hal ini menandakan investor lebih konservatif dalam menempatkan order. Sifat konservatif tersebut dapat dilihat dengan mendekomposisikan status order, yaitu: Amend, Match, Open dan Withdraw. Jika status nilai F statistik status order match lebih kecil dari tiga status order lainnya mengindikasikan investor konservatif.

Hasil pengujian hipotesis 2 memperlihatkan bahwa ada perbedaan rata-rata secara signifikan antara status order match dengan tiga status order lainnya (Lihat Tabel 2). Uji $F$ pada pembukaaan pasar menunjukkan nilai $\mathrm{F}$-open, inn match beli $=2,205, F$-open, inn open beli $=$ 7,479, F-open, inn amend beli $=6,363$ dan F-open, inn withdraw beli= 4,895. Karena F statistik order lot beli dan lot jual yang match lebih kecil dibandingkan dengan status order amend, open dan withdraw, maka dikatakan bahwa investor konservatif pada pembukaan pasar. Sebaliknya pada penutupan pasar order match menjadi lebih besar. Temuan tersebut konsisten dengan temuan Lee, Fok dan Liu (2001) Brock dan Kleidon (1991). Penemuan 
tersebut mendukung hipotesis kedua yang menyatakan investor lebih konservatif pada pembukaan pasar.

\section{Strategi Investor pada Pembukaan Pasar}

Dalam Tabel 3 dibawah ini menunjukkan bahwa kedua investor melakukan strategi yang sama, dimana keduanya menempatkan order lebih besar dan konservatif pada pembukaan pasar. Dan jumlah order informed investors lebih besar dari uninformed investors, hal tersebut dapat diketahui dari volume transaksi perdagangan pada setiap interval dan rata-rata lotnya. Kolom terakhir Tabel 3 menunjukkan rasio perbandingan order informed dan uninformed. Jika rasio tersebut digunakan untuk menguji perilaku perdagangan antara informed investors dan uninformed investors, dapat dikatakan keduanya berperilaku relatif berubah setiap waktu. Hal tersebut dapat dilihat dari jarak rasio interval 1 sampai interval 21 adalah berkisar pada 0,57-1,29.

Namun hasil uji ANOVA menunjukkan bahwa tidak ada perbedaan rata-rata yang signifikan antara kelompok informed investors dan uninformed (Lihat Tabel 3). Selain itu nilai F statistik memperlihatkan tidak ada rasio yang berbeda signifikan pada semua interval. Hasil ini menunjukkan bahwa hipotesis 3 tidak didukung. Hal ini menjelaskan bahwa investor tidak melakukan strategi dalam perdagangan, artinya perilaku perdagangan informed dan uninformed investors relatif stabil sepanjang waktu. Temuan tidak mendukung hipotesis 3 dan konsisten dengan temuan Lee, Fok dan Liu (2001).

\section{d. Hubungan Penempatan Order Investor dengan Volume Perdagangan.}

Tabel 4 menunjukkan bahwa penempatan order informed berhubungan signifikan dengan volume perdagangan pada setiap interval. Sedangkan penempatan order uninformed investors kebanyakan tidak berhubungan signifikan dengan volume perdagangan. Hasil temuan tersebut memberikan indikasi bahwa hanya order informed investors lebih berperan dalam menjelaskan pola volume perdagangan. Temuan ini tidak konsisten dengan temuan Lee, Fok dan Liu (2001) yang menyatakan bahwa kedua investor lebih berperan dalam menjelaskan hubungan perilaku perdagangan investor dengan volume perdagangan. Temuan ini hanya mendukung informed investors lebih dapat menjelaskan hubungan perilaku perdagangan dengan volume perdagangan. Sedangkan uninformed investors kurang atau tidak berperan signifikan dalam menjelaskan hubungan perdagangan dengan volume perdagangan.

Banyaknya total order perdagangan setiap interval belum tentu mencerminkan terjadinya transaksi match (Lihat Tabel 1) karena masih ada status order yang tidak match, yaitu: amend, open dan withdraw. Maka perlu dilakukan analisis pengaruh status order lain 
terhadap volume perdagangan. Tabel 5 menunjukkan bahwa sebagian besar status order amend, open dan withdraw tidak berpengaruh signifikan terhadap volume perdagangan. Hal ini berarti pola perilaku hubungan investor dengan volume perdagangan pada umumnya disetir oleh order match khususnya informed buy match and informed sale match.

\section{Kesimpulan}

Hasil penelitian menunjukkan bahwa para investor berkeinginan kuat menempatkan order pada pembukaan dan penutupan pasar dibandingkan dalam periode perdagangan. Besarnya order waktu pembukaan pasar mengindikasikan bahwa investor paling konservatif pada waktu pembukaan tersebut. Tindakan konservatif tersebut dapat dilihat dari banyaknya order pada waktu pembukaan yang belum terjadi transaksi menjadi status order match. Hal ini menjelaskan bahwa investor hanya "menguji' pasar pada waktu pembukaan ketika tingginya ketidakpastian pada saat pembukaan pasar. Selanjutnya, dalam rangka menguji strategi investor pada pembukaan pasar. Hasil penelitian juga menunjukkan bahwa kedua investor tidak melakukan strategi dalam menempatkan order. Hal tersebut terlihat dari tidak ada nilai $F$ statistik rasio perbandingan informed dan uninformed order yang signifikan di semua interval waktu. Hal ini menjelaskan bahwa perilaku perdagangan informed dan uninformed investors relatif stabil dari waktu ke waktu.

Hasil analisis regresi mengindikasikan bahwa informed investors berhubungan dengan volume perdagangan di semua interval waktu, namun tidak semua uninformed investors berhubungan di setiap interval waktu. Hal tersebut berarti hanya order informed lebih berperan menjelaskan perilaku volume perdagangan dibandingkan dengan order uninformed. Hasil regresi juga menemukan bahwa status order match berperan lebih dalam menentukan perilaku volume perdagangan intraday. Peran tersebut lebih ditentukan oleh informed buy match dan informed sale match. Sedangkan status order amend, open dan withdraw kurang berperan untuk dalam menentukan pola volume perdagangan intraday tersebut.

\section{DAFTAR PUSTAKA}

Abhyankar, D. Ghosh, E. Levin dan R J. Limmack. 1997, 'Bid-Ask Spreads, Trading Volume and Volatility: Intra-Day Evidence from the London Stock Exchange', Joumal of Business Finance \& Accounting, 23 (4), 0306-686X.

Admati, A.R dan P. Pfleiderer. 1988, 'A Theory of Intraday Patterns: Volume and Price Variability', Review of Financial Studies, Vol. 1, pp. 3-40.

Admati, A.R. 1989, 'Divide and Conquer: A Theory of Intraday and Day-of-the week Mean Effects', Review of Financial Studies, pp. 189-223. 
Brock, P., Chung, D. 2000, 'Informed and Uninformed ed Trading in an Electronic, OrderDriven Environment', The Financial Review 35, pp. 125-146.

Brock, W.A. and A.W. Kleidon. 1991, 'Periodic Market Closure and Trading Volume', Journal of Economic Dynamics and Control, Vol. 16, pp. 451-489.

Foster, D. and S. Viswanathan. 1990, 'A Theory of the Interday Variations in Volumes, Variance, and Trading Costs in Securities Markets', Review of Financial Studies.

Foster, D. and S. Viswanathan. 1994, 'Strategic Liquidity Trading with Asimmetrically Informed Traders and Long-Lived Information', Journal of Financial and Quantitative Analysis, Vol. 29, No.4

Gerety, M.S. and J.H. Mulherin. 1992, 'Trading Halts and Market Activity: An Analysis of Volume at the Open and the Close', Journal of Finance, Vol. 47.

Ho, Yan-Ki dan Cheung, Yan-Leung. 1991, 'Behavior of Intra-Daily Stock Return on an Asian Emerging Market-Hongkong', Applied Economic, 23, 957-966.

Lee, Tsung-Yi, Fok, Robert dan Liu, Jane-Yu. 2001, 'Explaining Intraday Pattern of Trading Volume from the Order Flow Data', Journal of Business Finance \& Accounting, 28(1) \& (2). pp. 1765-1784.

Mclnish, Thomas H, Robert A. Wood. 1991, 'Hourly Returns, Volume, Trade Size, and Number Of Trades', The Journal of Financial Research, Vol. XIV, No. 4

Obizhaeva, Anna dan Wang, Jiang. 2006,' Optimal Trading Strategy and Supply/Demand ynamics', Working Paper, 2006

Santoso, Singgih. 2007. Menguasai Statistik Di Era Informasi dengan SPSS 15 Elex Media Kompotindo.

Segara, Lydia dan Segara, Reuben. 2007, 'Intraday Trading Patterns in the Equity Warans and Equity Options Markets: Australian Evidence', The Australian Accounting Business \& Finance Journal, Vol. 1, No. 2

Slezak, S.L. 1994, 'A Theory of the Dynamics of Security Returns Around Market Closures', Journal of Finance, Vol. 49 (September), pp. 1163-211.

Wang. 1994, 'A model of competitive stock trading volume', Journal of Political Economic.

Wood, R.A., T.H. Mclnish and J.K. Ord 1985, 'An Investigation of Transactions Data for NYSE Stock', Journal of Finance, Vol. 40, pp. 723-39.

\section{LAMPIRAN-LAMPIRAN}

\section{Tabel 1}

Total Order Beli dan Jual

\begin{tabular}{cclcc}
\hline No. & Interval & Beli (Lot) & Jual (Lot) & $\begin{array}{c}\text { Total Beli+ jual } \\
\text { (Lot) }\end{array}$ \\
\hline 1 & Open & $54.997 .984,00$ & $97.256 .367,75$ & $152.254 .351,75$
\end{tabular}


Tabel: 2

\begin{tabular}{|c|c|c|c|c|}
\hline 2 & $09: 45$ & $23.069 .240,55$ & $32.566 .324,97$ & $55.635 .565,52$ \\
\hline 3 & 10:00 & $11.461 .755,52$ & $10.167 .637,23$ & $21.629 .392,74$ \\
\hline 4 & $10: 15$ & 7.599.300,77 & $7.315 .272,93$ & $14.914 .573,70$ \\
\hline 5 & $10: 30$ & $8.177 .582,69$ & $6.233 .330,16$ & $14.410 .912,85$ \\
\hline 6 & $10: 45$ & $6.574 .456,15$ & $5.799 .742,23$ & $12.374 .198,37$ \\
\hline 7 & $11: 00$ & $6.534 .738,88$ & $6.103 .736,12$ & $12.638 .475,00$ \\
\hline 8 & $11: 15$ & $5.511 .324,73$ & $5.982 .348,11$ & $11.493 .672,85$ \\
\hline 9 & $11: 30$ & $4.849 .778,54$ & $4.623 .992,17$ & $9.473 .770,71$ \\
\hline 10 & $11: 45$ & $5.516 .171,55$ & $5.904 .305,32$ & $11.420 .476,87$ \\
\hline 11 & $12: 00$ & $3.088 .375,90$ & $3.037 .313,79$ & $6.125 .689,69$ \\
\hline 12 & $13: 45$ & $5.946 .022,66$ & $5.057 .532,82$ & $11.003 .555,48$ \\
\hline 13 & 14:00 & $5.566 .907,70$ & $4.460 .127,40$ & $10.027 .035,11$ \\
\hline 14 & $14: 15$ & $6.287 .073,69$ & $5.607 .068,30$ & $11.894 .141,99$ \\
\hline 15 & $14: 30$ & $5.562 .714,85$ & $5.600 .031,31$ & $11.162 .746,16$ \\
\hline 16 & $14: 45$ & $7.484 .412,09$ & $5.794 .097,42$ & $13.278 .509,51$ \\
\hline 17 & 15:00 & $6.693 .305,93$ & $5.881 .287,71$ & $12.574 .593,65$ \\
\hline 18 & $15: 15$ & $6.369 .943,25$ & $5.275 .140,15$ & $11.645 .083,41$ \\
\hline 19 & $15: 30$ & $5.371 .522,70$ & $5.503 .056,48$ & $10.874 .579,18$ \\
\hline 20 & $15: 45$ & $6.364 .930,55$ & $7.009 .619,66$ & $13.374 .550,21$ \\
\hline 21 & $16: 00$ & $12.040 .656,93$ & $12.514 .839,60$ & $24.555 .496,53$ \\
\hline \multicolumn{2}{|c|}{ Rata-rata } & $9.765 .152,36$ & $11.794 .912,93$ & $21.560 .065,30$ \\
\hline \multicolumn{2}{|c|}{ F-open, inn : } & $4,493^{* * *}$ & $8,903^{* * *}$ & $6,981^{* * *}$ \\
\hline \multicolumn{2}{|l|}{ F-close, inn } & $3,591^{* * *}$ & $4,590^{* * *}$ & $4,130^{* * *}$ \\
\hline \multicolumn{2}{|l|}{ F-09:45, inn } & $2,923^{* * *}$ & $3,818^{* * *}$ & $3,408^{* * *}$ \\
\hline
\end{tabular}

\section{Sumber: Data diolah dengan SPSS versi 15}

\section{Keterangan:}

Semua order dibuat dalam lot, 1 lot sama dengan 500 lembar saham. "F-open" representasi pembukaan perdagangan, 9:45 menggambarkan interval 15 menit pertama (9:30-9:45) diluar pembukaan perdagangan, "F-inn" menggambarkan periode interval interior perda gangan jam 9:45-15:45, "F-close"menggambarkan interval akhir perda gangan dari jam 15:45-16:00 ***,**, indikasi tingkat signifikansi pada level $1 \%, 5 \%$ dan $10 \%$. 
Status order Amend, Match, Open dan Withdraw dalam Ukuran Lot

\begin{tabular}{|c|c|c|c|c|c|c|c|c|}
\hline \multirow{2}{*}{ Interval } & \multicolumn{2}{|c|}{ AMEND (A) } & \multicolumn{2}{|c|}{ Match (M) } & \multicolumn{2}{|c|}{ OPEN (O) } & \multicolumn{2}{|c|}{ Withdraw } \\
\hline & Beli & Jual & Beli & Jual & Beli & Jual & Beli & Jual \\
\hline Open & $4.853 .009,00$ & $8.018 .862,50$ & $4.595 .355,00$ & $6.789 .880,00$ & $38.376 .307,00$ & $74.811 .342,00$ & $7.091 .630,00$ & $7.636 .286,70$ \\
\hline $09: 45$ & $2.195 .590,23$ & $2.860 .285,04$ & $8.596 .691,70$ & $8.104 .233,35$ & $9.358 .981,09$ & $18.429 .526,00$ & $2.919 .058,54$ & $3.173 .637,70$ \\
\hline $10: 00$ & $1.459 .375,60$ & $1.394 .363,00$ & $4.756 .872,05$ & $4.345 .513,30$ & $2.970 .346,57$ & $2.967 .772,80$ & $2.275 .161,30$ & $1.459 .988,13$ \\
\hline $10: 15$ & $539.376,40$ & $811.698,40$ & $3.526 .898,29$ & $3.172 .376,69$ & $2.369 .142,11$ & $2.543 .323,82$ & $1.453 .247,94$ & $1.133 .083,96$ \\
\hline $10: 30$ & $505.412,20$ & $747.405,80$ & $4.004 .720,78$ & $2.925 .956,23$ & $2.297 .531,31$ & $1.888 .580,44$ & $1.167 .954,40$ & $807.842,73$ \\
\hline $10: 45$ & $458.562,40$ & $637.826,50$ & $3.336 .339,98$ & $2.991 .063,40$ & $1.603 .668,40$ & $1.523 .031,43$ & $1.175 .890,37$ & $647.820,90$ \\
\hline $11: 00$ & $444.398,00$ & $709.998,80$ & $2.950 .322,20$ & $3.191 .332,48$ & $1.666 .265,48$ & $1.537 .343,04$ & $1.473 .753,00$ & $665.061,80$ \\
\hline $11: 15$ & $381.444,20$ & $661.436,00$ & $2.630 .324,69$ & $3.505 .192,10$ & $1.566 .590,40$ & $1.210 .592,18$ & $981.254,44$ & $605.127,83$ \\
\hline $11: 30$ & $359.958,00$ & $401.459,00$ & $2.160 .221,33$ & $2.099 .200,13$ & $1.455 .874,01$ & $1.531 .494,04$ & $873.724,40$ & $591.839,00$ \\
\hline $11: 45$ & $2.121 .115,20$ & $265.437,60$ & $1.912 .922,23$ & $1.809 .731,87$ & $808.837,25$ & $1.232 .572,81$ & $551.806,20$ & $350.757,00$ \\
\hline $12: 00$ & $233.834,60$ & $209.287,20$ & $1.470 .177,15$ & $1.558 .181,90$ & $785.132,95$ & $661.889,89$ & $599.231,00$ & $607.954,80$ \\
\hline $13: 45$ & $451.261,00$ & $569.217,20$ & $2.856 .120,11$ & $1.941 .898,11$ & $1.754 .641,35$ & $1.760 .531,51$ & $884.000,20$ & $785.886,00$ \\
\hline $14: 00$ & $466.149,00$ & $441.289,00$ & $2.868 .986,30$ & $2.188 .230,05$ & $1.483 .932,00$ & $1.404 .545,95$ & $747.840,40$ & $426.062,40$ \\
\hline $14: 15$ & $516.325,00$ & $611.610,80$ & $3.208 .471,41$ & $2.972 .189,21$ & $1.666 .808,48$ & $1.413 .323,29$ & $895.468,80$ & $609.945,00$ \\
\hline $14: 30$ & $407.739,00$ & $485.088,00$ & $2.671 .930,40$ & $2.917 .623,40$ & $1.655 .164,45$ & $1.672 .493,54$ & $827.881,00$ & $524.826,38$ \\
\hline $14: 45$ & $395.606,60$ & $496.707,00$ & $4.154 .598,49$ & $2.966 .060,49$ & $2.206 .132,00$ & $1.659 .011,72$ & $728.075,00$ & $672.318,20$ \\
\hline 15:00 & $504.559,00$ & $485.225,95$ & $3.488 .417,42$ & $3.087 .596,12$ & $1.873 .117,91$ & $1.679 .418,14$ & $827.211,60$ & $629.047,50$ \\
\hline $15: 15$ & $606.542,00$ & $474.733,00$ & $3.109 .842,45$ & $2.221 .667,85$ & $1.829 .768,60$ & $2.067 .610,70$ & $823.790,20$ & $511.128,60$ \\
\hline $15: 30$ & $450.877,00$ & $544.736,00$ & $2.520 .096,10$ & $2.655 .969,80$ & $1.862 .106,60$ & $1.759 .944,68$ & $538.443,00$ & $542.406,00$ \\
\hline $15: 45$ & $429.110,00$ & $694.083,80$ & $3.339 .053,76$ & $3.568 .721,26$ & $1.927 .122,30$ & $2.206 .492,60$ & $669.644,50$ & $540.322,00$ \\
\hline $16: 00$ & $553.956,00$ & $682.115,00$ & $6.206 .034,59$ & $6.891 .827,28$ & $4.834 .794,20$ & $4.413 .655,32$ & $445.872,14$ & $527.242,00$ \\
\hline Rata-rata & $873.057,16$ & 1.057.279,31 & $3.541 .161,74$ & $3.424 .021,19$ & $4.016 .774,50$ & $6.113 .071,23$ & $1.330 .997,07$ & $1.116 .599,27$ \\
\hline F-open, inn: & $6,363^{* * *}$ & $9,687^{* * *}$ & $2,205^{* * *}$ & $2,266^{* * *}$ & $7,479 * * *$ & $14,343^{* * *}$ & $4,895^{* * *}$ & $7,715^{* * *}$ \\
\hline F-close, inn: & $4,018^{* * *}$ & $5,229^{* * *}$ & $2,973^{* * *}$ & $3,277^{* * *}$ & $4,691^{* * *}$ & $6,414^{* * *}$ & $3,682^{* * *}$ & $4,382^{* * *}$ \\
\hline F-09:45, inn: & $3,964^{* * *}$ & $5,354^{* * *}$ & $2,314^{* * *}$ & $2,326^{* * *}$ & $3,131^{* * *}$ & $5,203^{* * *}$ & $3,447^{* * *}$ & $4,499 * * *$ \\
\hline
\end{tabular}

Sumber: Data diolah dengan SPSS versi 15

\section{Keterangan:}

F statistik, "F-all" merepresentasikan semua interval perdagangan, " F-open" merupakan representasi dari pembukaan perdagangan, "09:45" representa si dari 15 menit interval pertama (09:30-09:45) diluar pra-pembukaan perdagangan, F-inn" sebagai representasi periode interior dari jam 09:45-15:45, "F-close" yaitu representasi interval akhir perdagangan 15:45-16:00 . Tanda ${ }^{* * *}, * *, *$ mengindikasikan tingkat signifikansi pada level $1 \%, 5 \%$ dan $10 \%$. 
Tabel 3

Status Order Inform dan Uninform (dalam LOT) Berdasarkan Status Order

AMEND (A) MATCH (M) OPEN (O)

Withdraw

\begin{tabular}{|c|c|c|c|c|c|c|c|c|c|c|c|c|c|c|c|c|c|}
\hline & & & \multicolumn{4}{|c|}{ UREIN (U) } & \multicolumn{4}{|c|}{ VvIInaraw } & \multirow{3}{*}{$\begin{array}{c}\text { Inf } \\
/ \\
\text { Un } \\
\text { inf }\end{array}$} \\
\hline & \multicolumn{2}{|c|}{ Buy } & \multicolumn{2}{|c|}{ Sell } & \multicolumn{2}{|c|}{ Buy } & \multicolumn{2}{|c|}{ Sell } & \multicolumn{2}{|c|}{ Buy } & \multicolumn{2}{|c|}{ Sell } & \multicolumn{2}{|c|}{ Buy } & \multicolumn{2}{|c|}{ Sell } & \\
\hline Interval & $\ln f$ & Uninf & Inf & Uninf & $\operatorname{lnf}$ & Uninf & $\ln f$ & Uninf & $\operatorname{lnf}$ & Uninf & $\ln f$ & Uninf & $\ln f$ & Uninf & $\operatorname{lnf}$ & Uninf & \\
\hline Open & 4918041 & 16651 & 7960715 & 58147.5 & 4544260 & 51095 & 6616232 & 173643.8 & 37814603 & 561704 & 74198616 & 612726.75 & 7064691 & 26939 & 7605149 & 31137 & 0.566 \\
\hline & 2157152 & 37660.22 & 2788031 & 45692.04 & 8307076.4 & 140144.3 & 7785504.4 & 146076.95 & 9148164 & 146904.09 & 18170132 & 205153.88 & 2795970 & 43535.5 & 3112983 & 27025.5 & 0.707 \\
\hline 10.00 & 1444818 & 14557.6 & 1370352 & 24011 & 4663215 & 93657.04 & 4255356.5 & 90156.79 & 2905528 & 64818.56 & 2764814 & & 2255998 & 19163.3 & 1446390 & 13598.1 & 1.13 \\
\hline 10.15 & 505845 & 10462.4 & 736068 & 15568.43 & 3318773.8 & 66350.2 & 2926357.8 & 66220.8 & 2250847 & 47277.43 & 2431096 & 56442.93 & 1385035 & 14709.9 & 1072402 & 11116.9 & 1.042 \\
\hline 10.30 & 496994 & 8418.2 & 733632 & 13773.75 & 3920525.5 & 84195.3 & 2918677.5 & & 2255249 & 42282.31 & 1843437 & & & 10785.4 & & & 1.243 \\
\hline 10.45 & 444152 & 14410.4 & 626784 & 11042.5 & 3286450.9 & 49884.07 & 2939658.9 & 51404.5 & 1570287 & 33381.40 & 1484993 & 38038.42 & 1166961 & 8929.36 & 641525 & & 1.136 \\
\hline $\begin{array}{l}11.00 \\
1115\end{array}$ & $\begin{array}{l}439087 \\
374699\end{array}$ & $\begin{array}{r}5311.2 \\
651898\end{array}$ & 701592 & $\begin{array}{r}8406.8 \\
0538\end{array}$ & $\begin{array}{l}2911436.9 \\
25884323\end{array}$ & 38885.34 & 3149544.9 & 41787.578 & 1634063 & 32202.47 & 1504005 & & 1465438 & & 658571 & 6490.8 & 1.073 \\
\hline 11.15 & $\begin{array}{l}374699 \\
55098\end{array}$ & 651898 & 6745.2 & & 2588432.3 & 3459288.3 & $\begin{array}{l}41892.4 \\
\end{array}$ & 45903.8 & 1536740 & 1173923 & 29850.4 & 36669.18 & 924973 & 598384 & 7992.44 & 6743.83 & 0.921 \\
\hline $\begin{array}{l}11.30 \\
11.45\end{array}$ & $\begin{array}{l}355098 \\
375232\end{array}$ & $\begin{array}{r}93361610 \\
5620.2\end{array}$ & $\begin{array}{r}4860 \\
645471\end{array}$ & $\begin{array}{l}7849 \\
9158\end{array}$ & $\begin{array}{l}21243441.8 \\
2549850.3\end{array}$ & $\begin{array}{r}20627733.8 \\
41222.21\end{array}$ & $\begin{array}{r}358880.33 \\
3400555.3\end{array}$ & $\begin{array}{r}364666.33 \\
45008.612\end{array}$ & $\begin{array}{l}1428396 \\
1554083\end{array}$ & $\begin{array}{r}1502361 \\
28996.4\end{array}$ & $\begin{array}{r}27478.01 \\
1174506\end{array}$ & $\begin{array}{l}29133.04 \\
36252.57\end{array}$ & $\begin{array}{l}867013 \\
952930\end{array}$ & $\begin{array}{l}586486 \\
8237.44\end{array}$ & $\begin{array}{l}6711.4 \\
586732\end{array}$ & $\begin{array}{r}5353 \\
6721.83\end{array}$ & $\begin{array}{l}1.049 \\
0.936\end{array}$ \\
\hline & 226967 & 6867.6 & 204851 & $\begin{array}{r}4436.2 \\
\end{array}$ & 1443424 & 26753.15 & 1532755 & & & $\begin{array}{l}28126.95 \\
185\end{array}$ & & & & & & 3243.8 & 1.019 \\
\hline 13.45 & 445219 & 6042 & 561504 & 7713.2 & 2816440.8 & 396 & 1913037.8 & & & 2010 & & & & & & 62 & 1.18 \\
\hline 14 & 462 & & 434999 & 6290 & 2795825 & 73161.304 & 2165488 & 2274 & 146 & 23697 & 1386959 & & 74 & 6082.4 & 422124 & 3938.4 & 1.25 \\
\hline 14.15 & 509910 & & 602919 & 8691.8 & 3164212.1 & 44259.28 & 2932298.1 & 3989 & 164 & 20742.47 & 1389567 & & 88 & 6620.8 & 604352 & 5593 & 1.12 \\
\hline 14.30 & 392923 & 14816 & 476636 & & & & & & & 1788 & 1645417 & & 821352 & 6529 & & & \\
\hline 14.45 & 391448.6 & & & 79 & & & & & & & & & & & & & 1.29 \\
\hline 15.00 & & & & 6773 & & & & & & 188 & & & & & & & 1.14 \\
\hline 15.15 & & & 4684 & 63 & & & 2190 & & & & & & & & & & 1.21 \\
\hline 15.30 & 44 & 4027 & 537957 & 67 & 2484748.5 & & & & & & & & & & & & 0.98 \\
\hline 15.45 & 425211 & 3899 & 686553 & 7530.8 & 3299503.6 & 39550.156 & 3530720.4 & 3800 & 1900689.3 & & & & & 3796.5 & 536808 & 14 & 0.91 \\
\hline $\begin{array}{l}16.00 \\
\text { Rata-Rata }\end{array}$ & $\begin{array}{l}5481152 \\
783928.65\end{array}$ & $\begin{array}{r}5804 \\
58246.42\end{array}$ & $\begin{array}{r}6747757 \\
1009050.8\end{array}$ & $\begin{array}{r}7358 \\
13403.04\end{array}$ & $\begin{array}{l}61371117.1 \\
\mathbf{3 5 0 6 2 4 2 . 4}\end{array}$ & $\begin{array}{r}68917.48 \\
312593.17\end{array}$ & $\begin{array}{l}68201922.2 \\
3166048.8\end{array}$ & $\begin{array}{l}716355.13 \\
62950.36\end{array}$ & $\begin{array}{l}4799107 \\
3987069\end{array}$ & $\begin{array}{r}35667.2 \\
184861.06\end{array}$ & $\begin{array}{r}43688827 \\
5889018.9\end{array}$ & $\begin{array}{l}44828.31 \\
\mathbf{9 3 0 2 . 1 1}\end{array}$ & $\begin{array}{r}443412 \\
1331907.3\end{array}$ & $\begin{array}{l}2460.14 \\
65669.8\end{array}$ & $\begin{array}{r}524672 \\
1060414.3\end{array}$ & $\begin{array}{r}2570 \\
8058.1217\end{array}$ & $\begin{array}{l}0.96 \\
1.04\end{array}$ \\
\hline F-open, inn: & $6.884^{* \star \star}$ & $9.208^{* * \star}$ & $9.121^{* * \star}$ & & $1.939^{* * \star}$ & $9.528^{* * *}$ & $2.010^{* * *}$ & $380^{* * \star}$ & $6.190^{* * *}$ & $15.997^{* * *}$ & $12.108^{* * *+}$ & & & $15.789^{* * *}$ & & $16.228^{* * *}$ & 1.38 \\
\hline $\begin{array}{l}\text { F-close, inn: } \\
\text { F-09:45, inn: }\end{array}$ & $\begin{array}{l}4.537^{\star \star *} \\
4.464^{\star \star \star}\end{array}$ & $\begin{array}{l}7.861^{\star \star \star} \\
8.017^{\star \star \star}\end{array}$ & $\begin{array}{l}5.017^{\star \star \star} \\
5.094^{\star \star \star}\end{array}$ & $\begin{array}{l}13.843^{\star \star \star} \\
14.975^{\star \star \star}\end{array}$ & $\begin{array}{l}2.742^{\star * *} \\
2.077^{\star \star *}\end{array}$ & $\begin{array}{l}9.863^{\star \star *} \\
9.998^{\star \star *}\end{array}$ & $\begin{array}{l}3.051^{\star \star *} \\
2.123^{\star \star \star}\end{array}$ & $\begin{array}{l}8.374^{\star \star *} \\
7.373^{\star \star *}\end{array}$ & $\begin{array}{l}4.445^{\star \star \star} \\
2.915^{\star \star \star}\end{array}$ & $\begin{array}{l}8.621^{\star \star \star} \\
8.585^{\star \star \star}\end{array}$ & $\begin{array}{l}5.747^{\star \star \star \star} \\
4.547^{\star \star \star}\end{array}$ & $\begin{array}{l}14.490^{* \star \star *} \\
\mathbf{1 4 . 9 4 2 ^ { \star \star \star * }}\end{array}$ & $\begin{array}{l}3.329^{\star \star \star} \\
3.171^{\star \star \star}\end{array}$ & $\begin{array}{l}14.622^{2 * \star} \\
\mathbf{1 3 . 2 6 5 ^ { * \star \star * }}\end{array}$ & $\begin{array}{l}4.349^{\star \star \star} \\
4.495^{\star \star \star}\end{array}$ & $\begin{array}{l}11.175^{* \star \star *} \\
\mathbf{1 0 . 7 0 6 ^ { * \star * }}\end{array}$ & $\begin{array}{r}1.43 \\
1.37\end{array}$ \\
\hline
\end{tabular}

Sumber: Data Diolah dengan SPSS versi 15

Keterangan :Informed order= order dengan ukuran lebih dari 20 lot, F statistik, " Open" merupakan representasi dari pembukaan perdagangan , "13.45" representa si dari 15 menit interval pertama (13:30-13:45) " "inn" yaitu representasi periode interior dari jam 14:45-15:45, "close yaitu representasi interval akhir perdagangan yaitu 15:45-16:00. Tanda ${ }^{* * *}, * * *$ mengindikasikan tingkat signifikansi pada level $1 \%, 5 \%$ dan $10 \%$. 
Tabel 4

Regresi Volume-Total Order

\section{VOLt = ao +a1 INFBt+ a2 INFSt+a3 UNFBt+a4 UNFSt+et}

\begin{tabular}{ccccll}
\hline Interval & Intercept & \multicolumn{1}{c}{ INFB } & \multicolumn{1}{c}{ INFS } & \multicolumn{1}{c}{ UNFB } & \multicolumn{1}{c}{ UNFS } \\
\hline Open & 0,346807 & $0,459812^{* * *}$ & $0,495444^{* * *}$ & $0,215994^{* *}$ & $-0,078703$ \\
$09: 45$ & $0,838596^{* * *}$ & $0,487460^{* * *}$ & $0,460706^{* * *}$ & $0,048644^{*}$ & 0,018778 \\
$10: 00$ & $1,113935^{* * *}$ & $0,678217^{* * *}$ & $0,256954^{* * *}$ & $-0,030258$ & $0,081625^{* * *}$ \\
$10: 15$ & $1,221054^{* * *}$ & $0,560795^{* * *}$ & $0,360680^{* * *}$ & $0,067585^{* *}$ & $-0,009838$ \\
$10: 30$ & $1,394131^{* * *}$ & $0,698300^{* * *}$ & $0,192194^{* * *}$ & $0,138823^{*}$ & $-0,055586$ \\
$10: 45$ & $1,077531^{* * *}$ & $0,693886^{* * *}$ & $0,238794^{* * *}$ & 0,047496 & 0,009912 \\
$11: 00$ & $0,945613^{* *}$ & $0,534805^{* * *}$ & $0,413775^{* * *}$ & 0,073786 & $-0,018294$ \\
$11: 15$ & $0,906177^{* * *}$ & $0,510312^{* * *}$ & $0,431450^{* * *}$ & 0,017158 & 0,05167 \\
$11: 30$ & $1,194147^{* * *}$ & $0,701819^{* * *}$ & $0,221799^{* * *}$ & $0,097870^{* * *}$ & $-, 0,042212^{* * *}$ \\
$11: 45$ & $0,920747^{* * *}$ & $0,476162^{* * *}$ & $0,462031^{* * *}$ & 0,03544 & 0,036571 \\
$12: 00$ & $1,205348^{* * *}$ & $0,504817^{* * *}$ & $0.406798^{* * *}$ & 0,009952 & 0,065247 \\
$13: 45$ & $0,836244^{* * *}$ & $0,517973^{* * *}$ & $0,422752^{* * *}$ & $-0,100634^{* * *}$ & $0,179855^{* * *}$ \\
$14: 00$ & $0,961163^{* * *}$ & $0,574070^{* * *}$ & $0,384280^{* * *}$ & $0,078561^{* * *}$ & $-0,046317^{* *}$ \\
$14: 15$ & $1,051443^{* * *}$ & $0,500515^{* * *}$ & $0,455312^{* * *}$ & 0,024909 & 0,00175 \\
$14: 30$ & $0,999402^{* * *}$ & $0,440446^{* * *}$ & $0,519087^{* * *}$ & 0,010725 & 0,017567 \\
$14: 45$ & $1,073298^{* * *}$ & $0,605405^{* * *}$ & $0,345464^{* * *}$ & 0,049829 & $-0,017181$ \\
$15: 00$ & $1,254599^{* * *}$ & $0,488848^{* * *}$ & $0,455963^{* * *}$ & $0,045787^{*}$ & $-0,028693$ \\
$15: 15$ & $1,453254^{* * *}$ & $0,513764^{* * *}$ & $0,467070^{* * *}$ & $0,067053^{* *}$ & $-0,040927$ \\
$15: 30$ & $0,630880^{* * *}$ & $0,396699^{* * *}$ & $0,579249^{* * *}$ & $-0,054751$ & $0,105529^{* * *}$ \\
$15: 45$ & $0,994480^{* * *}$ & $0,471362^{* * *}$ & $0,492177^{* * *}$ & $0,064427^{* * *}$ & $-0,041936^{*}$ \\
$16: 00$ & $0,925559^{* * *}$ & $0,532290^{* * *}$ & $0,438912^{* * *}$ & 0,028207 & $-0,007822$ \\
& & & & & \\
\hline 10 & & & & &
\end{tabular}

\section{Sumber: Data diolah dengan Eviews 4.1}

\section{Keterangan:}

Vol t: volume perdagangan pada waktu interval t, INFB dan INFS penempatan order jual dan beli oleh investor inform, UNFB dan UNFS adalah order beli dan jual dari investorn uninform, setiap interval di atas diregresikan pada 33 sampel perusahaan pada setiap interval, T statistik diperoleh dari regresi 33 sampel perusahaan. Tanda ${ }^{* * *},{ }^{* *}$ dan* adalah tingkat signifikansi pada $1 \%, 5 \%$ dan $10 \%$. 
Jurnal Manajemen Teori dan Terapan | Tahun 2, No.1, April 2009 | Ghazali Syamni 
Tabel 5

Regresi Volume - Amend, Match, Open, dan Withdraw

VOLt $=a 0+a 1$ INFBAt+ $a 2$ INFSAt+a3 UNFBAt+a4 UNFSAt+a5 INFBMt +a6 INFSMt+ a 7 UNFBMt+a8 UNFSMt $+a 9$ INFBOt +a10 INFSOt +a11 UNFBOt+a12 UNFSOt +a13INFBWt +a14 INFSWt +a15 UNFBWt +a16 UNFSW +

\begin{tabular}{|c|c|c|c|c|c|c|c|c|c|c|c|c|c|c|c|c|c|}
\hline $\begin{array}{c}\begin{array}{c}\text { Inter } \\
\text { val }\end{array} \\
\text { val }\end{array}$ & $\begin{array}{l}\text { Inter } \\
\text { sep }\end{array}$ & INFBA & INFSA & UNFBA & UNFSA & INFBM & INFSM & UNFBM & UNFSM & INFBO & INFSO & UNFBO & UNFSO & INFBW & INFSW & UNFBW & UNFSW \\
\hline Open & $1,953959^{* * *}$ & 0.139348 & -0.058166 & 0.004588 & -0.020856 & $0.296176^{* * *}$ & -0.045211 & $-0,25623^{*}$ & $0,355209^{* * *}$ & 0.112003 & $0,486366^{* * *}$ & 0.091499 & -0.002461 & $\begin{array}{l}-0.0104 \\
\end{array}$ & $0,057162^{*}$ & -0.045316 & -0.114406 \\
\hline 09.45 & $2,122785^{* * * *}$ & 0.178539 & 0.074467 & 0.019748 & $0,340649^{* * * *}$ & $0,380115^{* * * *}$ & $-0,20816^{* *}$ & -0.073264 & 0.189088 & 0.131741 & $0,372323^{* * * *}$ & 0.053212 & -0.013664 & $0.071377^{* *}$ & -0.014417 & 0.062152 & 0.143785 \\
\hline 10.00 & $2,816261^{* * *}$ & $0,301246^{* * *}$ & $0,180910^{* * * *}$ & -0.212142 & -0.163172 & $-0,39660^{* *}$ & $0,234621^{* * *}$ & $0,165840^{*}$ & $0,166390^{*}$ & $0,132181^{* * * *}$ & 0.112808 & 0.108937 & 0.05292 & 0.001115 & 0.297049 & -0.136856 & 0.165224 \\
\hline 10.15 & $2,727580^{* * *}$ & $0,096130^{* *}$ & -0.017261 & -0.033763 & $0,165522^{* * * *}$ & $0,195528^{* * * *}$ & $0,167447^{* * *}$ & 0.034229 & $0,127484^{* *}$ & $0,240522^{* * * *}$ & -0.051353 & 0.055789 & $0,119919^{*}$ & $0.104346^{* * *}$ & $0,137538^{* * * *}$ & $-0,112084^{*}$ & 0.038306 \\
\hline 10.30 & $2,357552^{* * *}$ & -0.001542 & 0.070506 & -0.094085 & -0.093147 & $0,534548^{* * * *}$ & 0.031569 & $0,300912^{* * *}$ & 0.076068 & $0,153345^{* * *}$ & -0.031538 & 0.014695 & 0.013142 & 0.025332 & 0.083326 & -0.048848 & -0.134855 \\
\hline 10.45 & $1,760967^{* * * *}$ & -0.027548 & 0.120673 & -0.079862 & 0.002003 & $0,543337^{* * * *}$ & 0.087602 & $0,192068^{*}$ & 0.099574 & 0.091736 & -0.043215 & 0.013677 & -0.036628 & 0.10595 & $0,048778^{* * * *}$ & $0,124756^{* *}$ & -0.014673 \\
\hline 11.00 & $2,500684^{* * *}$ & 0.055105 & 0.070893 & -0.001353 & $-0,28920^{* * * *}$ & 0.151111 & 0.185173 & $0,085095^{*}$ & 0.042855 & 0.010092 & $0,179614^{* *}$ & 0.072044 & 0.153552 & $0.181338^{* *}$ & 0.065394 & -0.019137 & 0.006628 \\
\hline 11.15 & $2,465655^{* * * *}$ & 0.037908 & -0.019994 & -0.099466 & $-0,185833^{*}$ & $0,202289^{* * * *}$ & 0.167096 & 0.177929 & 0.022818 & 0.171601 & 0.041578 & $0,160112^{* *}$ & 0.080218 & 0.121816 & $0,164411^{* *}$ & -0.094999 & -0.012829 \\
\hline 11.30 & $1,028,244$ & 0.027449 & -0.117058 & -0.045648 & -0.108882 & $0.442794^{* * *}$ & 0.085814 & 0.118807 & $0,267908^{* *}$ & 0.064316 & 0.123119 & -0.042134 & 0.037155 & 0.125965 & $0,199960^{* * * *}$ & -0.058218 & -0.038913 \\
\hline 11.45 & $1,913866 * * *$ & -0.005342 & 0.064322 & -0.074117 & -0.023182 & $0,545338^{* * * *}$ & $0,120490^{* * *}$ & 0.111758 & 0.10253 & 0.033582 & $0.053423^{* *}$ & -0.01835 & 0.006866 & 0.054688 & 0.043582 & -0.038881 & 0.003391 \\
\hline 12.00 & $2,107225^{* * * *}$ & 0.05814 & & & $-0,170311^{* *}$ & 0.126158 & 0.130503 & 0.156464 & 0.224002 & -0.055528 & $0,232416^{* * * *}$ & 0.145674 & -0.122829 & $0.165905^{* * * *}$ & 0.112907 & -0.00526 & -0.022876 \\
\hline 13.45 & $2,16252^{* * * *}$ & $0,174315^{*}$ & 0.145401 & $-0,090072^{*}$ & $-0,314186^{* *}$ & 0.240335 & $0,136692^{* *}$ & 0.026138 & 0.153003 & -0.098649 & $0,125951^{*}$ & 0.100805 & $0,129222^{* * *}$ & 0.091432 & 0.100888 & 0.084208 & -0.009324 \\
\hline 14.00 & $2,242458^{* * *}$ & -0.012493 & -0.021862 & 0.011301 & 0.022673 & $0,368332^{* * *}$ & $0,291800^{* * *}$ & 0.01634 & -0.015035 & $0,115978^{* *}$ & $0,104178^{* *}$ & -0.001721 & -0.075064 & 0.028209 & 0.088087 & 0.000475 & 0.030524 \\
\hline 14.15 & $1,818414^{* * * *}$ & $0,071256^{* *}$ & 0.055832 & 0.001625 & -0.052142 & $0,366277^{* * * *}$ & $0,165885^{* * * *}$ & $0,078871^{* *}$ & $0,078681^{* *}$ & $0,150213^{* *}$ & 0.135162 & 0.001065 & -0.029524 & -0.089631 & $0,076421^{* *}$ & 0.022218 & 0.007428 \\
\hline 14.30 & $2,149202^{* * *}$ & 0.021717 & -0.000974 & -0.001055 & $-0,154325^{* *}$ & $0,320346^{* * * *}$ & $0,224074^{* *}$ & -0.029958 & 0.012477 & $0,101993^{*}$ & $0,189463^{* * *}$ & 0.000473 & 0.063083 & 0.000158 & $0,111584^{*}$ & 0.024001 & 0.101076 \\
\hline 14.45 & $2,256457^{* * *}$ & 0.009023 & 0.041502 & -0.069228 & -0.051672 & $0,514599^{* * * *}$ & 0.085919 & 0.046566 & 0.021424 & 0.127782 & 0.093757 & 0.013419 & -0.059469 & -0.005471 & 0.084694 & 0.006069 & 0.093459 \\
\hline 15.00 & $2,250075^{* * * *}$ & 0.02918 & -0.064018 & 0.031232 & -0.070875 & $0,203695^{* *}$ & $0,361218^{* * *}$ & 0.001713 & 0.004159 & $0,093702^{*}$ & $0,217230^{* * * *}$ & -0.095187 & 0.029497 & 0.031851 & $0,108637^{*}$ & 0.050717 & 0.021954 \\
\hline 15.15 & $2,686272^{* * * *}$ & 0.157941 & -0.020102 & -0.024464 & 0.050776 & $0,267872^{* * *}$ & $0,060749 * *$ & 0.08493 & 0.064274 & -0.01526 & $0,354157^{* *}$ & 0.005553 & -0.14525 & -0.015148 & $0,151983^{*}$ & 0.003117 & -0.034885 \\
\hline 15.30 & $2,066361^{* * *}$ & 0.009813 & $0.072950^{*}$ & 0.009318 & -0.018526 & $0,187198^{* *}$ & $0,337291^{* * *}$ & -0.040958 & 0.026675 & $0,070099^{*}$ & $0,217438^{* * *}$ & 0.026426 & -0.002999 & 0.031204 & 0.028234 & 0.036565 & 0.017032 \\
\hline 15.45 & $1,799373^{* * * *}$ & 0.032168 & $0.058935^{* *}$ & 0.024305 & $0,045197^{* * * *}$ & $0,315913^{* * * *}$ & $0,219296^{* * * *}$ & $0,036724^{*}$ & -0.007914 & $0,125363^{* * * *}$ & $0,176789 * * *$ & $0,037573^{*}$ & -0.008642 & $0.045819^{* * * *}$ & -0.027242 & 0.004102 & -0.050128 \\
\hline 16.00 & $1,658387^{* * *}$ & -0.031574 & -0.017411 & -0.029485 & -0.038653 & $0,469511^{* * *}$ & $0,223127^{* * *}$ & 0.01375 & 0.047967 & 0.077424 & $0,162065^{* * *}$ & $0,118375^{* *}$ & -0.008923 & -0.001674 & 0.030769 & -0.004127 & -0.008419 \\
\hline
\end{tabular}

Sumber: Sumber: Data diolah dengan Eviews 4.1

\section{Keterangan:}

Volt: volume perdagangan pada waktu interval t, variabel independen INFB dan UNFS adalah investor inform dan uninform, 4 karakter huruf awal adalah identifikasi order jual dan beli. Karakter huruh terakhir (5) adalah indentifikasi match, amend, open dan withdraw. Setiap interval di perdagangan merupakan estimasi dari 33 sampel perusahaan. T-statistik merupakan hasil regresi dari 33 sampel perusahaan. ***, ** dan * mengindikasi tingkat signifikansi $1 \%, 5 \%$ dan $10 \%$. 
Jurnal Manajemen Teori dan Terapan | Tahun 2, No.1, April 2009 | Ghazali Syamni 